\title{
FERTILIZATION OF SPHAGNUM BOGS, ON THE BASIS OF CERTAIN FIELD EXPERIMENTS AT LETEENSUO
}

\author{
YRJÖ PESSI \\ Society of Peat Cultivation, Experimental Station Leteensuo
}

Received April 2, 1960

At the experimental station of Leteensuo a number of tests have been established and continued through a prolonged period in order to study the fertlizing questions connected with the cultivation of Sphagnum bogs. So far these tests have been evaluated in thorough treatments of the phosphate fertilizing experiments $(7,5)$. These experiments will therefore not be dwelt upon in the present work. Instead, we are now concerned with an experiment with increasing nitrogen quantities combined with stable manure fertilizing, and with a complete fertilizing experiment combined with liming.

It should be pointed out that, with respect to peat cultivation in Finland, nitrogen fertilizing particularly is a many-sided question requiring careful deliberation, because the necessity of using nitrogen fertilizer and the required quantity is dependent not only on the type of peat but also on the geographical location of the bog in question.

The nitrogen content of peat varies, for instance, with the peat type; on an average it is about $1.2 \%$ for Sphagnum peat and $2.3 \%$ for sedge peat (2). However, the nitrogen is present in the peat in a not easily soluble form; consequently, there is little ammonia and nitrate nitrogen. Actually, the quantity of inherent nitrogen in peat that can be used by cultivated plants is essentially dependent on the amount of nitrogen mobilization that may take place. This, in its turn, is governed by numerous factors; among other things it is a fact that mobilization occurs in a different manner in different types of peat. In high-quality fens mobilization is comparatively lively, although the geographical location of the bog has to be taken into account; in Sphagnum bogs, again, mobilization is poor. Relatively great differences can be noted in this respect. In South Finland, where the soil temperature in the summer is higher than in bogs of more northerly location, nitrogen mobilization in high-quality fens is abundant enough to make nitrogen fertilizing virtually unnecessary for any one of our cultivated plants. However, Sphagnum bogs are always in need of nitrogen 
fertilizing. The experiments described in the following throw light primarily on the significance of nitrogen fertilizing on a Sphagnum bog in South-Finland.

The tests were established by A. VEsı́ivi; they were later continued by J. Törmä (1944), U. E. Hirvensalo (1945-1946), A. Isotalo (1947-1952) and S. Mikкola (1953-1956). The results of the experiment have previously been described by Vesikivi $(7$, p. 70$)$ and by TAKaLA (5).

\section{Test area and plans of experiment}

The peat of the test area is Sphagnum peat, mainly originating from $S p h$. fuscum moss. The peat layer has a thickness of more than 3 metres. The area was drained by open ditches, dividing it into strips $20 \mathrm{~m}$ in width.

\section{Complete fertilizing experiment}

The area was cleared for cultivation in 1932. In the winter of 1934, clay was added as a soil improving agent in a quantity of $300 \mathrm{~m}^{3}$ per hectare. In the same year the test area was also fertilized with stable manure at 35 tons per hectare.

The various treatments represented the fertilizer combinations P, PK, NP,
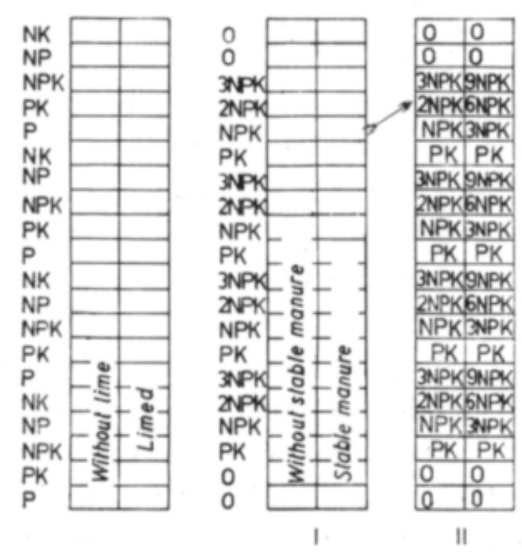

Fig. 1. The positicn of plots in the complets fertilizing and nitrogen fertilizing tests. I $=$ treatments up to $1949, \mathrm{II}=$ treatments since 1949 in the nitrogen fertilizing test.

NK and NPK. Liming was also combined with this experiment. The location of the treatments can be seen from Fig. 1. The fertilizers were given once a year. Liming was done in 1934 , when $2000 \mathrm{~kg}$ slaked lime per hectare were given. The fertilizers employed in the test were superphosphate or Kotka phosphate, 40 or $50 \%$ potassium salt, and calcium nitrate. The following nutrient quantities were applied per hectare:' $40 \mathrm{~kg} \mathrm{P}_{2} \mathrm{O}_{5}, 80 \mathrm{~kg} \mathrm{~K} \mathrm{~K}_{2} \mathrm{O}$, and $30 \mathrm{~kg} \mathrm{~N}$. Stable manure was applied to the entire test area in the spring of 1934 at a rate of 35 tons per hectare. The meadows were established as clover-timothy meadows. 
At the Experimental Station of Northern Ostrobothnia a fertilizing and soil improvement test has been carried out in which the fertilizer combinations were the same as in the present test, except that there was a plot without fertilizing instead of our P treatment and that heavier phosphate fertilization was given. The liming, too, was done with greater lime quantities (1, p. 8).

\section{Nitrogen fertilizing experiment}

The area was cleared for cultivation in 1921. The first cultivated plant was sown in 1923, at which time the test proper began. In 1923 the area received clay as a soil improving agent in a quantity of $300 \mathrm{~m}^{3}$ per hectare. In the same year, moreover, liming was performed, adding $4000 \mathrm{~kg}$ slaked lime per hectare.

Originally, increasing nitrogen fertilizer quantities and stable manure were combined in this field experiment as follows: One of two strips $10 \mathrm{~m}$ in width and $100 \mathrm{~m}$ in length received per hectare altogether 20 tons stable manure in 19231924, 30.6 tons in 1929, 30 tons in 1930, and 30 tons in 1933. Otherwise both strips carried the same treatments: $0, \mathrm{PK}, \mathrm{NPK}, 2 \mathrm{NPK}$, and $3 \mathrm{NPK}(\mathrm{N}=15 \mathrm{~kg} \mathrm{~N}, \mathrm{P}=$ $40 \mathrm{~kg} \mathrm{P}_{2} \mathrm{O}_{5}, \mathrm{~K}=100 \mathrm{~kg} \mathrm{~K}{ }_{2} \mathrm{O}$; all per hectare). In 1949 the plan of the experiment was altered in that the nitrogen fertilizer quantities given to the test plots in the strip with stable manure were increased so that the new nitrogen fertilizer quantities were $6 \mathrm{~N}$ and $9 \mathrm{~N}$ (see location of treatments, Fig. 1). In 1948, the after-effect of nitrogen fertilization was studied. The fertilizers employed in this experiment were calcium nitrate, superphosphate and potassium salt.

\section{Crop yield results}

The weather conditions during the years of experiment have been described in a previous publication (4, p. 5).

The hay meadows have been timothy-dominated. Usually a seed mixture containing $20 \mathrm{~kg}$ timothy seeds and $5-8 \mathrm{~kg}$ red clover seeds per hectare has been used. The seed quantity of oats was $200-220 \mathrm{~kg}$ well-germinating seed per hectare, except in 1958, when only $160 \mathrm{~kg}$ per hectare were used. The hay and straw crop yields have been given as in an air-dried state, the grain crop yields as dried.

\section{Complete fertilizing experiment}

The annual crop results in this experiment are shown in Table I in the Appendix, while Tables 1 and 2 give the average crop yields per year. Table 3 contains calculated values showing the degree of crop increase caused by each one of the three nutrients when given in addition to a basic administration of the other two. These values were computed from the crop yield of the completely fertilized plot, subtracting the figures obtained with the two-component combinations, each one in turn. The results reveal that nitrogen has the greatest significance among the three, with phosphorus next and potassium ranging last. This succession in importance of the fertilizers is consistent with the findings of Antrinen (1, p. 13). Most closely 
Table 1. Complete fertilizing experiment. Average hay crop yields, $\mathrm{kg}$ per hectare and year (17 years).

\begin{tabular}{|c|c|c|c|c|c|}
\hline & \multicolumn{2}{|c|}{ Without lime } & \multicolumn{2}{|c|}{ Limed } & \multirow{2}{*}{$\begin{array}{c}\text { Increase in } \\
\text { yield due to } \\
\text { liming }\end{array}$} \\
\hline & Crop yield & $\begin{array}{c}\text { Increase in } \\
\text { yield }\end{array}$ & Crop yield & $\begin{array}{c}\text { Increase in } \\
\text { yield }\end{array}$ & \\
\hline $\mathrm{P}$ & 1770 & - & 2920 & - & 1150 \\
\hline PK & 1510 & -260 & 2840 & -80 & 1330 \\
\hline NP & 3310 & 1540 & 4060 & 1140 & 750 \\
\hline NK & 2040 & 270 & 2640 & -280 & 600 \\
\hline NPK & 3080 & 1310 & 4410 & 1490 & 1330 \\
\hline
\end{tabular}

Significant differences:

$\begin{array}{llll}\text { Artificial fertilization } & 108 * & 144 * * & 187 * * * \\ \text { Liming } & 172 * & 229 * * & 298 * * *\end{array}$

Table 2. Complete fertilizing experiment on Sphagnum bog. Average grain and straw yields of oats, $\mathrm{kg}$ per hectare and year (5 years).

\begin{tabular}{|c|c|c|c|c|c|c|c|}
\hline \multirow[b]{2}{*}{ Fertilization } & \multicolumn{2}{|c|}{ Without lime } & \multicolumn{2}{|c|}{ Limed } & \multirow[b]{2}{*}{$\begin{array}{l}\text { Increase in } \\
\text { yield due to } \\
\text { liming }\end{array}$} & \multicolumn{2}{|c|}{ Straw yield } \\
\hline & Grain yield & $\begin{array}{l}\text { Increase } \\
\text { in grain } \\
\text { yield }\end{array}$ & Grain yield & $\begin{array}{c}\text { Increase } \\
\text { in grain } \\
\text { yield }\end{array}$ & & $\begin{array}{l}\text { Without } \\
\text { lime }\end{array}$ & Limed \\
\hline $\mathbf{P}$ & 1450 & - & 1420 & - & -30 & 3140 & 3970 \\
\hline PK & 1240 & -210 & 1550 & 130 & 310 & 2470 & 4070 \\
\hline NP & 1990 & 540 & 1920 & 500 & -70 & 4810 & 4930 \\
\hline NK & 1890 & 440 & 1690 & 270 & -200 & 3600 & 3900 \\
\hline NPK & 2090 & 640 & 2010 & 590 & -80 & 4700 & 4880 \\
\hline Significa & differences & & & $A 4$ & & & \\
\hline
\end{tabular}

Table 3. Values showing the degree of crop increase $(\mathrm{kg} / \mathrm{ha})$ caused by each one of the three nutrients when given in addition to a basic administration of the other two. $\mathrm{I}=$ unlimed, $\mathrm{II}=$ limed.

\begin{tabular}{lrrrr}
\hline & $\mathrm{N}$ & $\mathrm{P}$ & $\mathrm{K}$ \\
\hline Hay I & & 1570 & 1040 & -230 \\
II & & 1570 & 1770 & 350 \\
Oats, grain yield I & 850 & 200 & 100 \\
& II & 460 & 320 & 90 \\
& & & \\
Oats, straw yield I & 230 & 1100 & -110 \\
& II & 810 & 980 & -50
\end{tabular}

comparable with the present experiment are the basic treatments in his investigation, i.e., stable manure plus clay, and stable manure plus clay plus lime. One observes particularly the slight effect of potassium, in fact the yield-lowering effect of potassium. The effect of phosphate fertilizers on Sphagnum bog can be seen in detail 
in the investigation of TAKALA (5). In table 4 are shown the results of one phosphate trial, which has been evaluated by TAKALA ( $\mathrm{P}=20 \mathrm{~kg} \mathrm{P}_{2} \mathrm{O}_{5}$ per ha).

Tables 1 and 2 reveal that liming considerably increases the hay crop yields but has a lowering effect upon the grain crops of oats. The same observation was made in all other Sphagnum bog liming experiments at Leteensuo (3, 4, p. 8-11).

Table 4. Average annual yields of hay in one phosphate trial at Leteensuo, $\mathrm{kg}$ per ha (during 9 years) (according to TAKalA). $\mathrm{P}=20 \mathrm{~kg} \mathrm{P}_{2} \mathrm{O}_{5}$ per ha, $s f=$ superphosphate, $\mathrm{tf}=$ basic slag.

\begin{tabular}{|c|c|c|c|c|c|}
\hline Fertilization & Yield & $\begin{array}{l}\text { Increase } \\
\text { in yield }\end{array}$ & Fertilization & Yield & $\begin{array}{l}\text { Increase } \\
\text { in yield }\end{array}$ \\
\hline 0 & 1904 & - & $0+$ liming & 2256 & 352 \\
\hline Psf & 4149 & 2245 & Psf + & 4588 & 2684 \\
\hline $\mathrm{Ptf}$ & 3341 & 1437 & $\mathrm{Ptf}+$ & 3375 & 1471 \\
\hline $2 \mathrm{Psf}$ & 4481 & 2577 & $2 \mathrm{Psf}+$ & 5254 & 3350 \\
\hline $2 \mathrm{Ptf}$ & 3470 & 1566 & $2 \mathrm{Ptf}+$ & 3422 & 1518 \\
\hline
\end{tabular}

Table 4 shows that in connection with liming the effect of phosphorus was particularly enhanced in regard to the hay crops. Furthermore, the figures relating to the crop increase produced by potassium seem to indicate that the relation between potassium and calcium might also have significance with respect to the effect of potassium. The same trend can also be observed in Antrines's findings (1, p. 13).

\section{Nitrogen fertilizing experiment}

The preceding experiment has revealed the great importance of nitrogen in the fertilization of Sphagnum bogs. The nitrogen fertilizing experiment provides an opportunity to study the effect of varying nitrogen dosages.

The annual crop yield results in this experiment can be seen from Table II in the Appendix.

Table 5. Average hay crop yields up to $1949, \mathrm{~kg}$ per hectare and year (13 years).

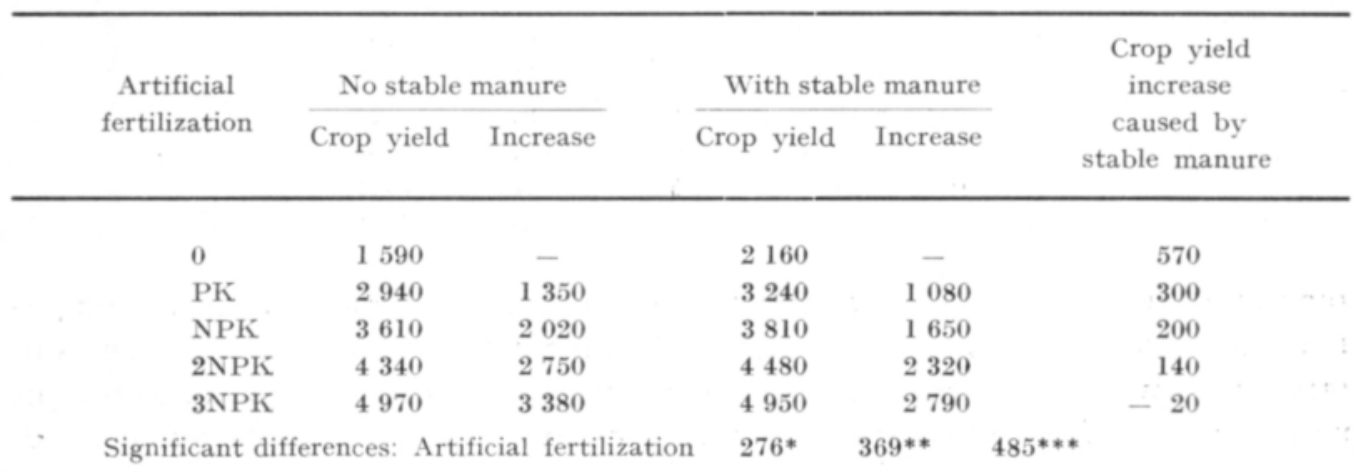


Table 6. Average crop yields of hay and oats since 1949, kg per hectare and year (Plan of experiment altered in 1949).

\begin{tabular}{|c|c|c|c|c|c|}
\hline \multirow{2}{*}{ Fertilization } & \multicolumn{2}{|c|}{ Hay (7 years) } & \multicolumn{3}{|c|}{ Oats (3 years) } \\
\hline & Crop yield & Increase & Grain yield & Increase & Straw yield \\
\hline 0 & 2010 & - & 960 & - & 2110 \\
\hline PK & 3510 & 1500 & 1240 & 280 & 3040 \\
\hline NPK & 3980 & 1970 & 1720 & 760 & 3680 \\
\hline 2NPK & 4840 & 2830 & 1820 & 860 & 4300 \\
\hline $3 N P K$ & 6140 & 4130 & 2120 & 1160 & 4780 \\
\hline $6 \mathrm{NPK}$ & 7330 & 5320 & 2680 & 1720 & 6920 \\
\hline 9NPK & 7110 & 5100 & 2730 & 1770 & 7720 \\
\hline
\end{tabular}

Meadows. Tables 5 and 6 and Figs. 2 and 3 show the average hay crop yields per year up to 1949 and since that year. The results were grouped in this way because the plan of the experiment was altered in 1949. It can be seen that the highest

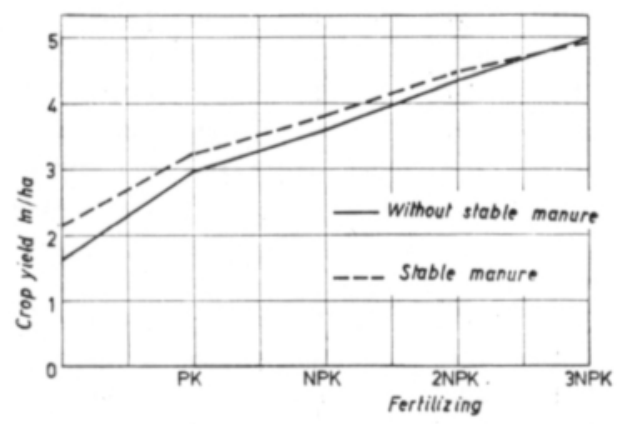

Fig. 2. Average hay crop yields per year in the nitrogen fertilizing test up to 1949 (13 years).

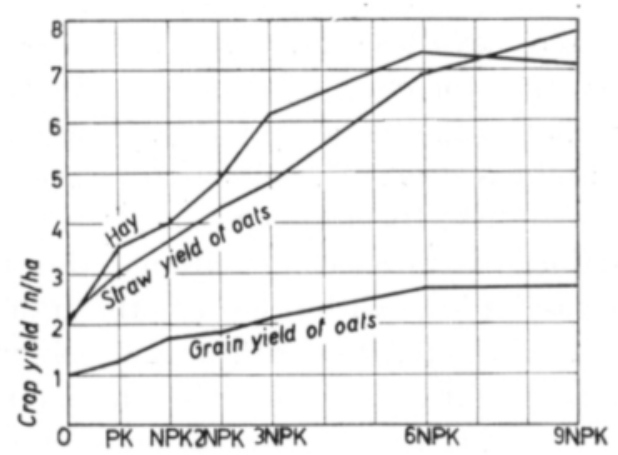

Fig. 3. Average crop yields of hay and oats per year in the nitrogen fertilizing test since 1949 . 
nitrogen dosage included in the original plan, $45 \mathrm{~kg} \mathrm{~N}$ per hectare, has been too small for hay meadows, since the crops increased fairly linearly up to the dosage of $6 \mathrm{~N}$. Table 5 and Fig. 2 reveal that stable manure increased the hay crop yield when little or no nitrogen was used; its hay crop-increasing effect becomes less with in creased nitrogen fertilizing. However, the difference is not statistically significant.

Cereals. In addition to hay, only oats and mixed peas and oats were used as experimental plants, except in 1959 , when also barley was cultivated. The average crops, per year, of oats and of mixed peas and oats are shown in Tables 6 and 7

Table 7. Average grain and straw yields up to $1949, \mathrm{~kg}$ per hectare and year, for oats (grain crops of 6 years, straw crops of 5 years) and for mixed peas and oats (5 years).

\begin{tabular}{|c|c|c|c|c|c|}
\hline \multirow{3}{*}{$\begin{array}{r}\text { Artificial } \\
\text { fertilization }\end{array}$} & \multicolumn{2}{|c|}{ No stable manure } & \multicolumn{2}{|c|}{ With stable manure } & \multirow{2}{*}{$\begin{array}{l}\text { Crop yield increase caused } \\
\text { by stable manure }\end{array}$} \\
\hline & Grain Increase & Straw & Grain & Straw & \\
\hline & yleid Increase & yield & yield & Increase yield & Grain yield Straw yield \\
\hline
\end{tabular}

\begin{tabular}{|c|c|c|c|c|c|c|c|c|}
\hline & & & & $\mathrm{O}$ at $\mathrm{s}$ & & & & \\
\hline 0 & 650 & - & 1680 & 1000 & - & 2900 & 350 & 1220 \\
\hline PK & 700 & 50 & 2440 & 1060 & 60 & 3720 & 360 & 1280 \\
\hline NPK & 950 & 300 & 3050 & 1270 & 270 & 4310 & 320 & 1260 \\
\hline $2 N P K$ & 1120 & 470 & 3670 & 1460 & 460 & 4940 & 340 & 1270 \\
\hline 3NPK & 1330 & 680 & 4150 & 1540 & 540 & 5300 & 210 & 1150 \\
\hline
\end{tabular}

Significant differences: Artificial fertilization $41 * 55 * * \quad 75 * * *$

Stable manure $65 * 88 * * 119 * * *$

\begin{tabular}{|c|c|c|c|c|c|c|c|c|}
\hline 0 & 860 & - & $\begin{array}{r}\mathrm{Pe} \\
1660\end{array}$ & $\begin{array}{l}\mathrm{nd} \\
1270\end{array}$ & s & 2490 & 410 & 830 \\
\hline PK & 1680 & 820 & 3250 & 1780 & 60 & 3740 & 100 & 490 \\
\hline NPK & 1880 & 1020 & 3930 & 2060 & 790 & 3990 & 180 & 60 \\
\hline 2NPK & 1920 & 1060 & 4050 & 2030 & 760 & 4230 & 110 & 180 \\
\hline $3 \mathrm{NPK}$ & 2150 & 1290 & 4500 & 2110 & 840 & 4540 & -40 & 40 \\
\hline
\end{tabular}

and Figs. 3 and 4; they, too, have been given separately for the period before and after 1949. It can be seen that the curves representing the crop yield figures have a course largely similar to that of the hay crop yields. However, Table 7 reveals that the effect of stable manure was different, both with respect to grain and to straw yield, from that in the case of hay. Its crop-increasing effect was equal in magnitude in connection with all artificial fertilizer combinations. Also, this effect was statistically significant in every case at least with respect to the grain yield, as the $\mathrm{F}$ values indicate. The corresponding characteristic for the straw yield was not computed.

Prolonged effect of stable manure. The effect of stable manure can still be observed in 1948 , as late as 15 years after the most recent addition of stable manure to the proper test member. The crop yield increases possess statistical significance, the $\mathrm{F}$ value, 8.5, rating one asterisk. The prolonged effect of stable manure is also 
evident from the fact that in the years $1934-1940$, when no more stable manure was added, the increases in hay crops as well as in the grain crops of oats, caused by stable manure, were equal in magnitude to those during earlier years.

If we compute the average effect of stable manure from the PK combination test and from all PKN tests, we find that it increased the average hay crops of the four hay meadows in the period $1934-1940$ by $340 \mathrm{~kg}$ per hectare and year, while the corresponding figure for the period 1925-1928 (four hay meadows) was only $78 \mathrm{~kg}$ per hectare and year. Similar calculations show that the oats grain yield increased, owing to stable manure, by $570 \mathrm{~kg}$ in 1938 , while in the three years when the stable manure addition was performed, i.e., 1923, 1930, and 1933, the average increase was $400 \mathrm{~kg}$ per hectare and year. The cause for the favourable effect of stable manure is likely to be found, partially at least, in the changes in microbial activity in the soil produced by it.

\section{Crop quality}

Studies relating to the quality of the crops exist only from the nitrogen fertilizing experiment. In 1958, the timothy content of the hay (from a seventh year ley) was investigated (5, p. 34). The timothy percentage of the different treatments, starting with the plot, withouth treatment, was found to be: $2.4 ; 13.1 ; 11.0 ; 26.8 ; 56.9 ; 72.5$; 54.3. The timothy percentage was thus highest in the test member with $90 \mathrm{~kg} \mathrm{~N}$ per hectare. In the instance of the test member with the highest nitrogen fertilizer dosage the lodging of the hay, which would have given other plant species a better chance to gain the upper hand, is thought to be responsible for the fact that the timothy percentage went down once more $(5$, p. 35$)$.

Table 8. Strength of straw, 1000-grain weight and shooting capacity in 1958. Experimental plant: Orion III oats.

\begin{tabular}{lccc}
\hline Fertilization & $\begin{array}{c}\text { Strength of straw } \\
(0-10)\end{array}$ & $\begin{array}{c}\text { 1000-grain } \\
\text { weight, }\end{array}$ & Shooting, \% \\
\hline PK & 10 & 31.8 & 29 \\
NPK & 10 & 31.1 & 8 \\
2NPK & 10 & 30.2 & 6 \\
3NPK & 10 & 29.7 & 8 \\
6NPK & 10 & 31.4 & 5 \\
9NPK & 6.5 & 31.0 & 4
\end{tabular}

Table 8 shows the results and observations from the crop quality determinations to which the oat crops of 1958 were subjected. Nitrogen fertilizing did not lower the 1000 -grain weight to any noteworthy extent but it effected a slight reduction in the germinability. Impaired germinability was, namely, experienced that year, owing to night frosts. However, there are no significant differences in germinability be- 
tween the crops reared with different nitrogen fertilizer dosages. The lodging of the crops in two test members, too, was caused by severe night frost $\left(-13.0^{\circ} \mathrm{C}\right)$. This lodging serves to indicate that the highest nitrogen fertilizer dosages have produced a straw of different structure. On the other hand it does not necessarily indicate that the development of the cereal would have been markedly delayed in the test members with the highest nitrogen dosage, seeing that the germinability was reduced in all test members.

\section{Conclusions}

The present investigation is an account of the results from two fertilizing experiments established on Sphagnum bog at the Experimental Station of Leteensuo. The experiments were carried out in 1923 and 1934. The following conclusions can be drawn from the results.

Most important in significance among the different nutrients is nitrogen, phosphorus ranging next, and potassium last. Potassium could even cause a reduction in the crop yields.

The effect of liming was evident in the form of increased hay crops, whereas the grain yields of oats were reduced by it. Liming has improved the effect of phosphorus particularly in the case of hay. The results also seem to indicate that the relation between potassium and calcium has significance in regard to the reduction of crop yield caused by potassium.

Remarkable crop yield increases were obtained by nitrogen fertilizing. The hay crops and the grain and straw crops of oats increased almost linearly with the addition of nitrogen, in the form of calcium nitrate, in quantities up to $90 \mathrm{~kg} \mathrm{~N}$ per hectare. Quantities in excess of this caused hardly any further increase in the crops. The said quantity is suitable for cover manuring of hay meadows, but the most advisable quantity for cereals is thought to be $45-60 \mathrm{~kg} \mathrm{~N}$ per hectare, so that lodging of the crops might be avoided.

Nitrogen fertilization does not essentially affect the quality of the grain crops of cereals; on the other hand nitrogen promoted the retention of timothy in the meadow when nitrogen was used in quantities up to $90 \mathrm{~kg}$ per hectare.

Stable manure increased the crops. This effect was most distinctly evident in the grain and straw crops of oats. The effect of stable manure was still present 15 years after the most recent addition of stable manure.

\section{REFERENCES}

(1) Antrinen, O. 1957. Rahkasuon lannoitus- ja maanparannuskokeen tuloksia. Referat: Ergebnisse eines Düngungs- und Bodenverbesserungsversuchs auf. Sphagnum-Moor. Valt. Maatal. koetoim. julk. 155: 1-29.

(2) Krvinen, E. 1948. Suotiede: Porvoo. 219 p.

(3) PeSsi, Y. 1958. Rahkasuoviljelyksen kalkituksesta. Summary: On the liming of cultivated Sphagnum bogs. Suovilj. yhd. v.k. 52-62: $29-32$. 
(4) PESSI, Y. 1959. Kivennäismaan vaikutuksesta rahkasuon maanparannusaineena Leteensuon koeaseman pitkäaikaisten kenttäkokeiden perusteella. Summary: On the effect of mineral soil as a soil improving agent on Sphagnum bogs on the basis of prolonged field tests at Leteensuo Experimental Station. Acta agr. fenn. 94, 14: 241-268.

(5) TAKAlA, M. 1958. Salpietarilannoituksen vaikutuksesta niittonurmen satoon rahkasuolla. Summary: On the influence of nitrate fertilization upon the yield of hay meadows on Sphagnum peat bogs. Suovilj. yhd. v.k. 52-62: 33-36.

(6) - 1959. Suoviljelysten fosfaattilannoituksesta. Summary: On phosphate fertilization of peat soil. Ibid. $63: 30-38$.

(7) Vesikivi, A. 1935. Suomen suoviljelysyhdistyksen koeasemien v:n 1934 koetuloksia. I. Leteensuon koeasema. Ibid. 39: 70 .

S E L O S T S :

\title{
RAHKASUON LANNOITUS ERÄIDEN LETEENSUON KOKEIDEN PERUSTEELLA
}

\section{YRJö PESSI}

\author{
Suoviljelysyhdistys, Leteensuo
}

Tutkimuksessa on selostettu Leteensuon koeaseman rahkasuolle perustettujen lannoituskokeiden tuloksia. Koealueen turve on vähän maatunutta, Sphagnum fuscum rahkaturvetta. Koealueelle on lisätty savea maanparannusaineeksi $300 \mathrm{~m}^{3} / \mathrm{ha}$. Seuraavat päätelmät voidaan esittää.

Eri ravinteista on tärkein merkitys typellä, sitten fosforilla ja viimeksi kalilla. Kalilannoitus on jopa saattanut alentaa satoja.

Kalkituksen vaikutus on ilmennyt siten, että heinäsadot ovat sen vaikutuksesta lisääntyneet, mutta kauran jyväsadot alentuneet. Kalkitus on parantanut fosfaattilannoituksen vaikutusta erityisesti heinällä. Tulokset viittaisivat myös siihen, että kalin ja kalkin suhteella on merkitystä kalin vaikutuksen kannalta.

Typpilannoituksella on saatu huomattavat sadonlisäykset. Heinåsadot sekä kauran jyvä- ja olkisadot ovat nousseet lähes suoraviivaisesti lisättäessä typpeä kalkkisalpietarin muodossa aina 90 kg N/ha. Tätä suurempi määrä ei ole juuri lisännyt satoja. Heinänurmen pintalannoitukseksi mainittu määrä soveltuu, mutta viljalle lienee suositeltavin $45-60 \mathrm{~kg} \mathrm{~N} /$ ha lakoviljan välttämiseksi.

Viljan jyväsadon laatuun ei typpilannoituksella liene sanottavaa merkitystä, mutta timotein säilymistä nurmessa on typpilannoitus edistänyt käytettäessä typpeä aina $90 \mathrm{~kg} / \mathrm{ha}$.

Karjanlanta on lisännyt satoja. Selvimmin tämä vaikutus on esiintynyt kauran jyvä- ja olkisadoissa. Karjanlannan vaikutus on ilmennyt vielä 15 vuoden kuluttua viimeisestä karjanlannan lisäyksestä. 
Table I. Complete fertilizing experiment on Sphagnum bog. Crop yields, annually, kg per 0.1 hectare. $\mathbf{I}=$ unlimed, $\mathrm{II}=$ limed.

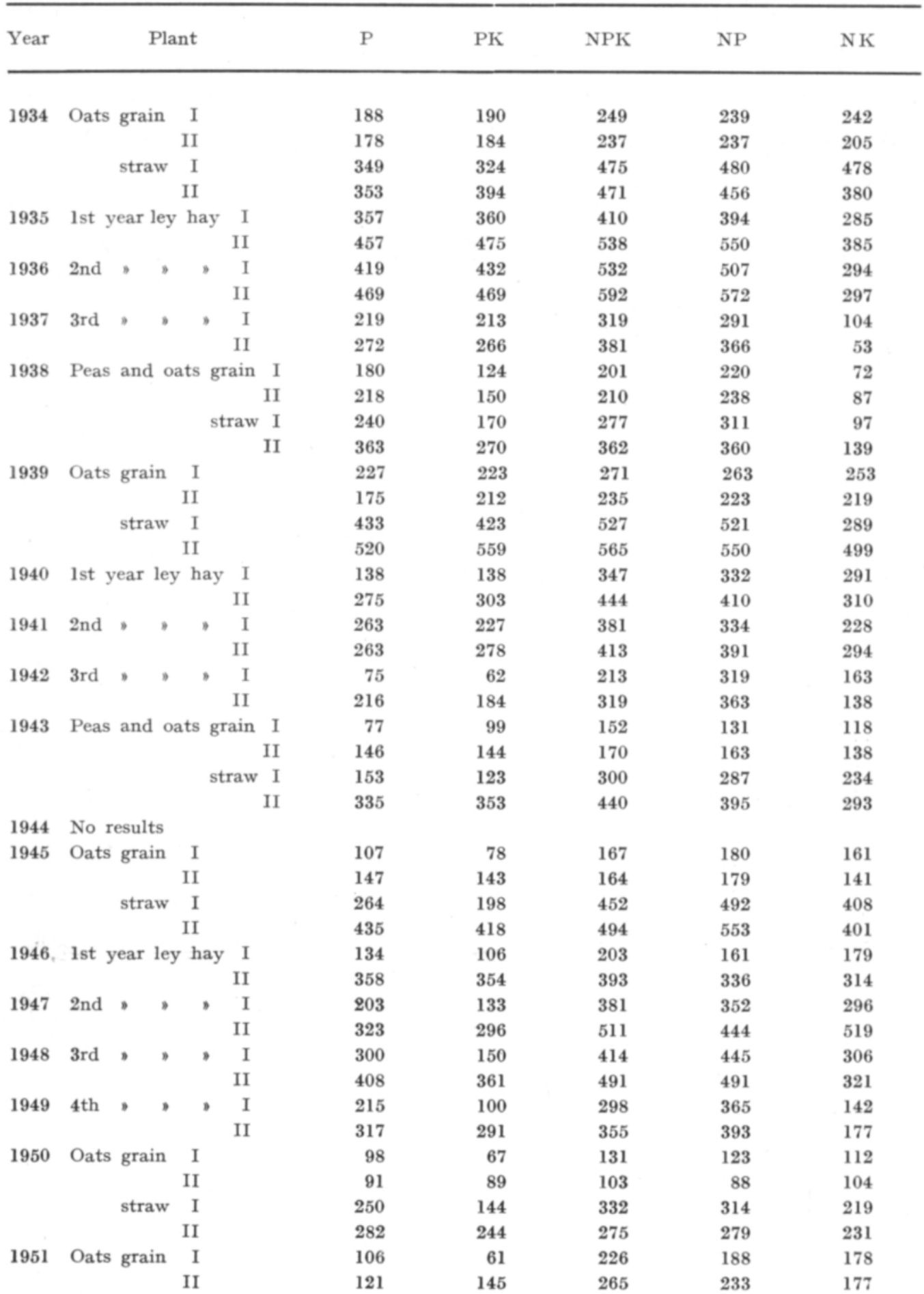




\begin{tabular}{|c|c|c|c|c|c|c|c|c|c|c|}
\hline \multirow[t]{2}{*}{ Year } & \multicolumn{5}{|c|}{ Plant } & $\mathrm{P}$ & PK & NPK & $\mathrm{NP}$ & NK \\
\hline & & stra & aw & & & 252 & 148 & 565 & 599 & 406 \\
\hline & & & I & & & 397 & 419 & 635 & 625 & 437 \\
\hline \multirow[t]{2}{*}{1952} & 1st & year & ley 1 & hay & I & 146 & 116 & 413 & 422 & 215 \\
\hline & & & & & II & 305 & 303 & 417 & 399 & 236 \\
\hline \multirow[t]{2}{*}{1953} & 2nd & , & , & , & I & 56 & 40 & 257 & 259 & 164 \\
\hline & & & & & II & 291 & 293 & 464 & 419 & 304 \\
\hline \multirow[t]{2}{*}{1954} & 3rd & . & , & , & I & 91 & 33 & 249 & 302 & 173 \\
\hline & & & & & II & 291 & 280 & 470 & 434 & 309 \\
\hline \multirow[t]{2}{*}{1955} & 4 th & , & , & , & I & 68 & 17 & 208 & 285 & 170 \\
\hline & & & & & II & 186 & 174 & 390 & 330 & 264 \\
\hline \multirow[t]{2}{*}{1956} & 5 th & , & , & , & I & 114 & 46 & 263 & 318 & 192 \\
\hline & & & & & II & 247 & 220 & 465 & 403 & 290 \\
\hline \multirow[t]{2}{*}{1957} & 6 th & , & , & , & I & 106 & 35 & 198 & 266 & 98 \\
\hline & & & & & II & 158 & 154 & 463 & 328 & 121 \\
\hline \multirow[t]{2}{*}{1958} & 7 th & , & . & , & I & 104 & 41 & 144 & 281 & 163 \\
\hline & & & & & II & 137 & 135 & 386 & 283 & 151 \\
\hline
\end{tabular}

Table II. Experiment with increasing nitrogen quantities. Crop yields, annually, kg per 0.1 hectare. $\mathrm{I}=$ without stable manure, $\mathrm{II}=$ with stable manure.

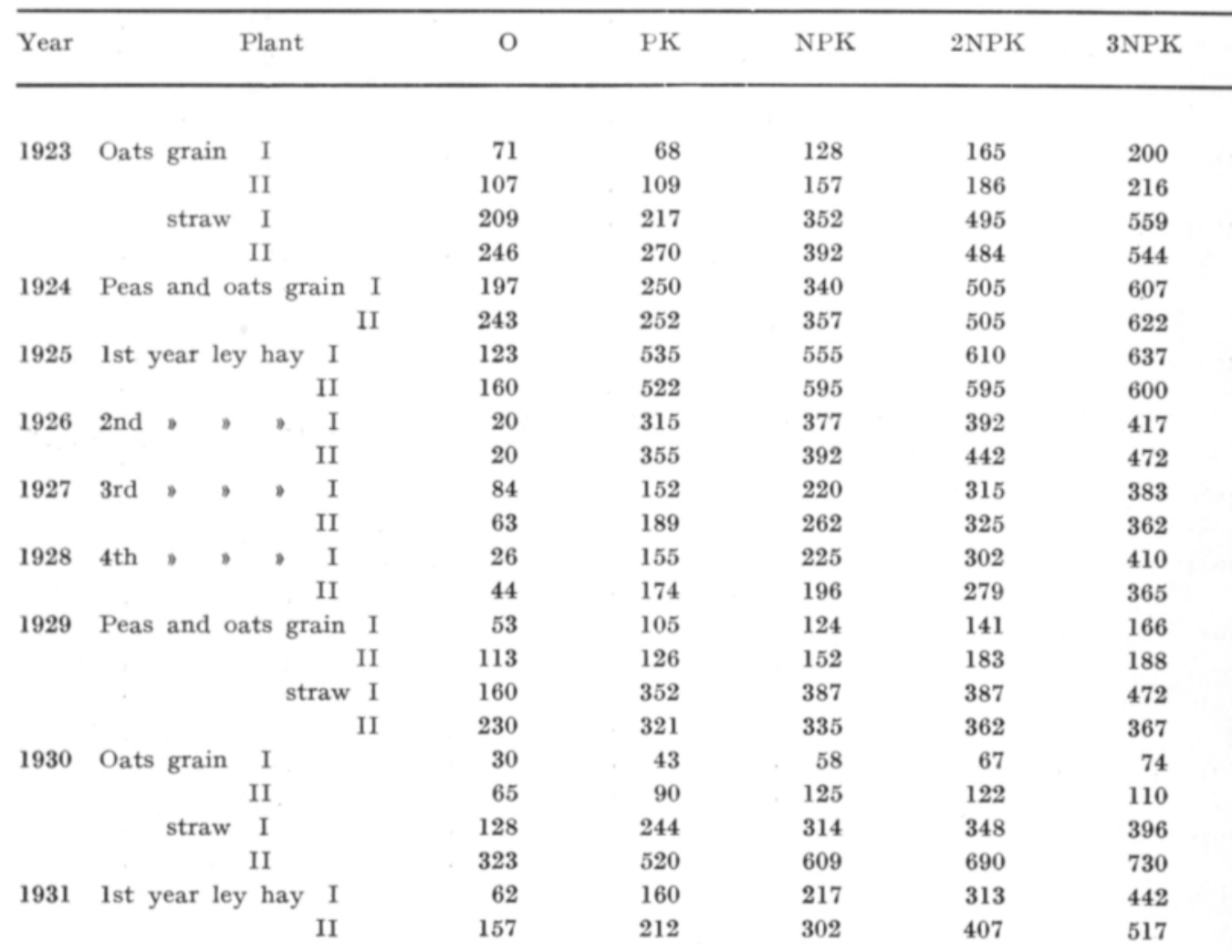




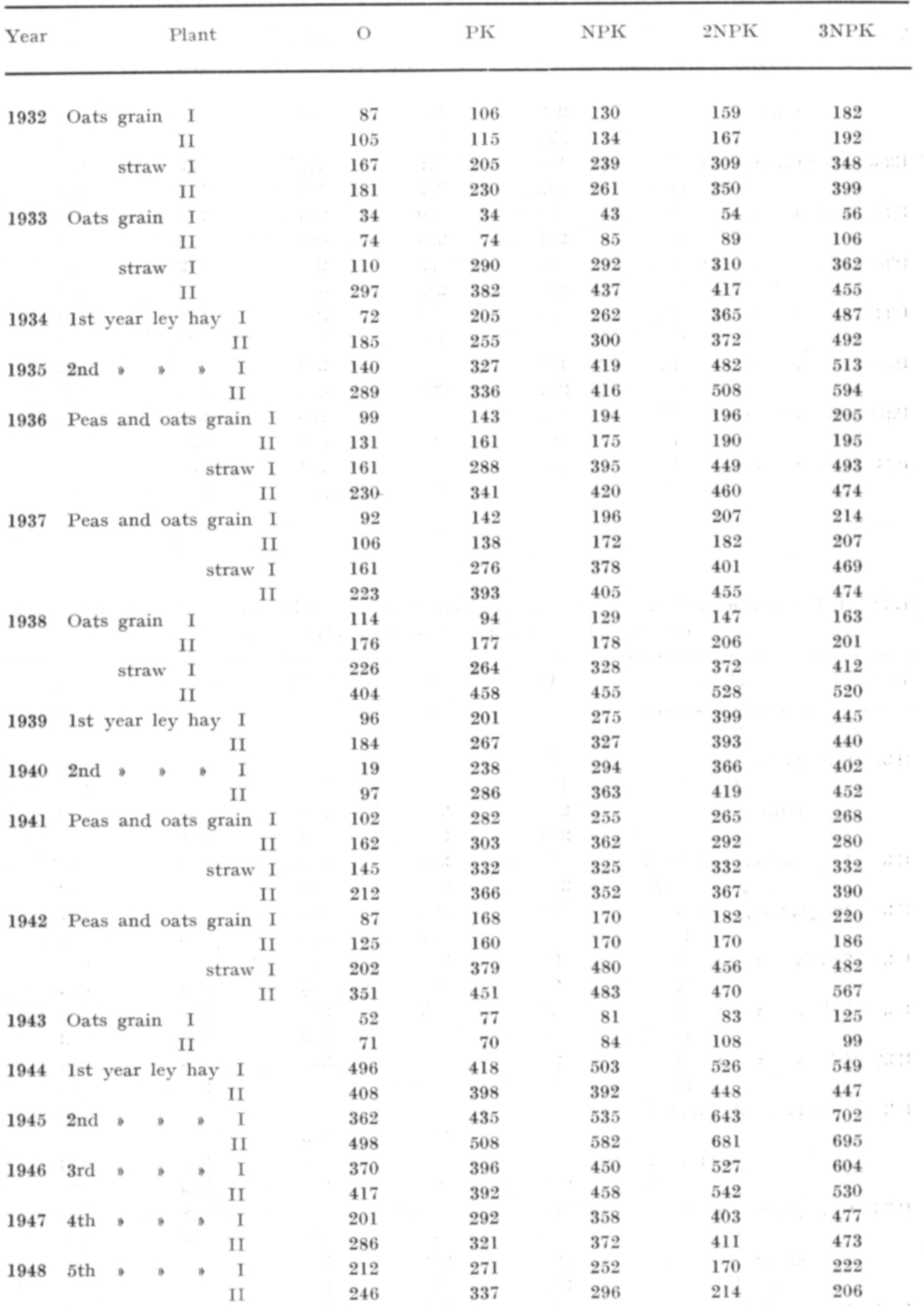


PK NPK 2NPK 3NPK 6NPK 9NPK

1949 Oats grain

1950 Oats grain straw

1951 lst year ley hay

1952 2nd, ,

1953 3rd , ,

1954 4th , ,

19555 th , ,

1956 6th , ,

1957 7th , ,

1958 Oats grain

$$
\text { straw }
$$

1959 Barley grain straw

\section{0}

\section{PKe}

15

28

73

16
259

105

198

236

237

165

205

59

181

38

176
$184 \quad 261$

$323 \quad 356$

$100 \quad 120$

$288 \quad 243$

$509 \quad 540$

$\begin{array}{ll}392 & 449\end{array}$

392

392
320

320
254

320

320
269

269

88
300

300
52

225
287

$411 \quad 464$

$124 \quad 187$

$261 \quad 264$

$607 \quad 692$

$530 \quad 647$

$596 \quad 738$

$403 \quad 563$

$378 \quad 519$

$444 \quad 552$

$431 \quad 584$

$134 \quad 145$

$619 \quad 706$

$81 \quad 124$

$339 \quad 430$
$317 \quad 340$

$524 \quad 492$

$280 \quad 270$

$566 \quad 562$

$744 \quad 720$

$838 \quad 775$

$766 \quad 715$

$631 \quad 596$

$744 \quad 714$

$634 \quad 614$

$771 \quad 841$

$206 \quad 208$

$987 \quad 1262$

$214 \quad 180$

$517 \quad 423$ 